\title{
A Clash of Communication? Intervening in Textbook Writing and Curriculum Development in Bosnia and Herzegovina After the War of 1992-1995
}

Falk Pingel

Various institutions and players participate in consultations on international textbook and curriculum revision: ministries of education, pedagogical-oriented as well as subject-oriented academic institutes, teacher associations and international organizations. Although all of them may agree on the common aim to contribute to the reform of education systems, they often differ in specific objectives and strategies of how to reach the common aim. They are used to act in different contexts such as political, educational or scientific environments, which are imprinted by specific traditions and attitudes of negotiating and problem-solving. In this respect, particularly political and scientific approaches may differ or even exclude each other. Whereas political bargaining is searching for legitimate compromise, science builds on a truth-finding process aiming at an intersubjective objectivity (Habermas 1984).

\footnotetext{
F. Pingel $(\square)$

Georg Eckert Institute, Braunschweig, Germany e-mail: fpingel@gmx.de

(C) The Author(s) 2017

C. Psaltis et al. (eds.), History Education and Conflict Transformation, DOI 10.1007/978-3-319-54681-0_9
} 
This chapter deals with advantages and limits of communication and negotiation strategies stakeholders in textbook and curriculum revision chose to cope with the problem of how to follow their own agenda and to cooperate with partners in reaching the common goal.

These issues will be inquired taking as an example the year-long consultations on textbook and curricula reform, which took place after the war of 1992-1995 in Bosnia and Herzegovina (henceforth BaH). Although one deals here with consultations between different stakeholders within a country — and not between different states—also features normally characteristic of international revision projects are included in the Bosnian case. The international community played a crucial role in the whole process, and some of the Bosnian players acted as if they were opponents in an international context because they rejected the official concept according to which $\mathrm{BaH}$ represents a united society and one state.

\section{Changing Patterns of International Textbook Revision}

Traditionally, international textbook research and revision has been performed as a school-subject-oriented analysis followed by joint recommendations agreed upon by the involved partners in a project. Analysis and recommendations evaluated the breadth and depth as well as correctness and compliance of the issue at stake with results of academic research and referred mainly to content issues. Although leading documents on objectives and methods of textbook revision touched upon the pedagogical and psychological dimensions of textbook research from its very beginnings, official bi- or multilateral national commissions as well as academic projects often play down or almost neglect the pedagogical aspects and psychological implications of textbooks and curricula as instruments of teaching and learning. The scientific correctness has been regarded as a proof for the intended objectivity and political neutrality of findings and recommendations for revision (Faure 2015; Pingel 2010a).

The broad pedagogical and sociological debate about the impact of globalization, the emerging knowledge society and a rapidly changing world order since the 1980s questioned this traditional model and fostered trends to pay more attention to the context and conditions which frame the use pupils and teachers make of curricula and teaching material. UNESCO as one of the leading agencies for the improvement in educational structures worldwide underscored this trend when the organization developed its report "Learning to be" (Faure et al. 1973), 
which propagated the concept of lifelong learning. The report strove to make education experts in UNESCO's member states aware of the need for learning processes that are open to changing environments. The traditional teacher-centred way of instruction should be altered into classroom environments that support democratic communication structures and develop pupils' activities and participatory learning. When referring to UNESCO's long-standing engagement in education towards international understanding, the report expressly takes into account Piaget's "genetic psychology" as a scientific approach to the intended new education model (Pingel 2016). Yet, born in the time of rapprochement after the height of the Cold War and fostered through the breakdown of the bipolar world order after the dissolution of the Soviet bloc, the new model of an interactive consensual, democratic education process was severely shattered through ongoing or new conflicts springing up particularly in Africa and South Asia as well as in some of the former socialist countries, $\mathrm{BaH}$ being one of them. Experts in education policy and economy-often affiliated with international organizations-directed international attention to the devastating effects violent conflicts have on education. They underscored that history and civic education have been abused for legitimizing conflict and fostering adversary images and negative stereotyping of the "other" (Seitz 2004; Smith and Vaux 2002; Bush and Saltarelli 2000). With the adoption of the "Education for All Dakar Framework for Action" (UNESCO 2000) in the year 2000, UNESCO made "quality education" its overall concept concentrating on regions affected by severe undernourishment and protracted armed conflict. The turn to internal conflicts in the revision of curricula and teaching material-instead of almost exclusively dealing with wars between states as in the past-and the new emphasis on learning processes pushed the question to the fore which role education has in strengthening or weakening social cohesion in conflict or post-conflict societies. It was UNESCO's "International Bureau of Education" (Piaget was its director from 1929 to 1968), which first expressly addressed the topic in a substantial publication in 2004 dealing with the role of education in conflict-ridden societies in Europe, Asia, the Middle East, Latin America and Africa (Tawil and Harvey 2004). However, it took almost a decade before theories of learning and social psychology have been applied as well in a publication dealing with textbook revision (Perikleous and Shemilt 2011). It was not by chance that this time an NGO (the Association for Historical Dialogue and Research) was the publisher 
reflecting the increasing role civil society initiatives play in developing educational strategies aiming at fostering the understanding for peaceful conflict resolution in education.

\section{The Need for Symmetry: Seeking Balance AND RECOGNITION}

With the significant involvement of NGOs, the need for establishing balance, symmetry and mutual recognition within revision projects has come to the fore. In the traditional model of politically induced and often also financed and approved bi- or multinational commissions, the political authorities set the formal ramifications of a project including the content areas which should be dealt with and sometimes also the qualifications which should be represented in the commission if the authorities themselves did not appoint members. Thus, the general working procedures are defined by sovereign governmental institutions with equal standing. Scholarly analysis then guarantees the objectivity of the working process and the political neutrality of recommendations. In contrast, NGO-geared groups can be composed of lay persons, academics, politicians with quite different social statuses, qualifications and working experiences. As no supervising political authority exists, group members have to elaborate procedures and content areas themselves. Whatever the qualifications and political views of participants in a project are, they must be seen as equivalent and of equal value lending the same argumentative power to all sides involved.

Social psychology theories have emphasized that symmetric relations between partners in problem-solving activities are a basic requirement for fostering cooperative attitudes and innovative thinking (Shultziner 2010; Kelman 2009; Rouhana and Kelman 1994). Piaget has delivered the most profound explanation based on experiment and theoretical analysis as Gerard Duveen has shown referring to the children's transition from pre-operational to operational thinking. According to Piaget, "symmetric relations" are needed to stimulate productive, innovative knowledge and to create an environment of cooperation rather than "constraint" (Duveen 2002), as constraints may be seen any kind of authoritative impediments that hinder free and open thinking. In fact, adults are more flexible in responding to constraints and may even challenge restrictions set by authorities, but such reactions would create a climate of fighting for superiority and symmetry-impeding competition. 
A cooperative basis must be agreed upon as a starting point if issues of clashing collective identities are at stake and multiple perspectives and opposing views are represented within a project. As a rule, members of revision commissions are well minded, willing to cooperate and to overcome mistrust and biased views which help to find a common basis. However, groups with adversarial, clearly defined self-characterizations as they occur in situations of protracted civil war, strong ethnic nationalism and unequal power relations perceive each other as in-group and outgroup and tend to reinforce their exclusive group identities in encounters with their "adversaries" (Amir 1976; Turner et al. 1987; Tajfel and Turner 1986). In this case, short-term dialogical encounters between the groups may not help to overcome stereotype and mistrust as could be expected according to a simple application of the contact hypothesis. Further research on the contact hypothesis has shown that the reduction in stereotypes is not only a matter of correct information and reasonable intellectual argumentation in joint meetings. Encounters must be accompanied by positive emotions leading to acknowledgement and recognition of the "other". Situations of practical cooperation must be created that show that all parties involved depend on each other in order to produce a common result (Oskamp 2000; Brewer and Miller 1988).

The social and epistemological dimensions of learning inextricably underlie the controversial dialogue between the parties with the aim to reach a common understanding of the conflict at stake. The late Israeli professor of social psychology, D. Bar-On, has devoted year-long research and practical group work with the aim to establish symmetry of communication between persons and groups with different, even contrasting experiences and historical backgrounds. In contact with children of holocaust survivors and Nazi perpetrators, he created a dialogical method based on biographical storytelling, which should lay foundations for a dialogue on equal footing (Bar-On 1995). He transferred his method to encounters between Israelis and Palestinians with the aim to jointly develop teaching material about the Israeli-Palestinian relationship which could be used in Israeli as well as Palestinian schools (Adwan et al. 2012; Bar-On and Kassem 2004). Telling each other's life stories has the function to distract attention from the dividing political dimension. So to speak, it individualizes and humanizes politics. It shows how the political dimension influences human lives. Personal experiences cannot be refuted: they are neither right nor wrong. Their narrative structure deviates from the model of binary logic. Life stories show how and 
why group members act under the impact of heavy political constraints. This is an experience member of both sides share. Mutually listening to life stories brings about empathy and furthers trust and recognition of the "other". Whereas Bar-On's approach is influenced by psychoanalytical thinking, experimental social psychological research has also underscored the positive effects of empathy and described perspective taking exactly as what has taken place in Bar-On's groups, namely to "increase the perception that a common humanity and destiny is shared with the other group" (Brown and Hewstone 2005:293). Biographical storytelling is just a means to make people ready for what Pettigrew has defined as "self-disclosure": to open oneself to others (Pettigrew 1998). Biographical storytelling stands at the beginning of Bar-On's projects, accompanies them at each phase and paves the way for the proper historical and pedagogical work on the teaching material. Bar-On has called this approach TRT (= To Reflect and Trust) (Bar-On et al. 2000). The TRT concept is not easily applicable because it presupposes the involvement of psychologically trained moderators, prolongs the group's work and claims from the participants to bring in their own personality, to present their personal experiences to persons who are regarded as enemies by the majority of one's own society. Usually, its application is restricted to small groups, and it is mostly used by NGO-driven projects. It can hardly be applied in official expert commissions.

Besides Bar-On's special approach, W. Fisher and others have formed a more general theory of narrative communication as a counter-model to binary argumentative logic (Fisher 1984). The stories' coherence and the sincerity of the narration and the narrator create confidence and allow the listeners to relate themselves to the experiences of the "other".

Whereas the biographical approach strives to generate empathy and positive feelings within a project from the very beginning and to take out politics as long as possible, J. Rothman (1997) has developed a contrasting model of dialogical identity conflict resolution containing four phases. It starts expressly with a confrontational "antagonism phase" during which participants exchange their conflicting political views. When participants come to the conclusion that a continuation of the political debate would not produce any common results, they are asked to rationally define their own positions and interests, to compare them with the ones of the adversary and so develop step by step an understanding of possible common goals and to work on solutions. He calls his model according to the four steps ARIA (= Antagonism, Resonance, 
Invention, Action). Rothman's model surely comes closer to normal working procedures of official revision commissions though they use it informally or implicitly rather than systematically and consciously. It builds more on rational argumentation and reason than on personal trust and empathy.

\section{Bosnia and Herzegovina: From Political Negotiations to AN Expert Dialogue}

When textbook and curriculum revision began in $\mathrm{BaH}$, neither local authorities nor the International Community $(=\mathrm{IC})^{1}$ had much systematic knowledge at hand of how to steer such a process. It was not even clear whether one could regard this as an internal Bosnian process not considerably different from normal changes of educational conditions as they happen in any country from time to time, or whether the example of international textbook and curricula commissions could serve as an appropriate paradigm to set the structure for the intended Bosnian reform. In fact, it was something in between. To understand this situation, I have to shortly recall the political conditions in $\mathrm{BaH}$ after the conclusion of the Dayton Peace Accords in 1995.

$\mathrm{BaH}$ has been divided into two political entities, the Serb Republic with its own ministry of education and the Federation of Bosnia and Herzegovina. The latter consists of 10 cantons with local governments in addition to the government of the Federation. Yet, the Federation's ministry of education has only a coordinating role between the cantonal education ministries and its room for manoeuvre is always contested. Thus, education foremost played a negative role in the peace regulations. In order to pay respect to the strive for cultural autonomy of the so-called constituent peoples of $\mathrm{BaH}$ - the Serbs, Croats and Bosniaks ${ }^{2}$ - the education system was entirely federalized. Soon after the war, broadly speaking, three different streams of education were formed: a Serb oriented in the Serb Republic, a Croat oriented in the Croat majority cantons and a Bosniak stream in the Bosniak majority cantons, amongst them the capital Sarajewo. Whereas the Serb and Croat systems adopted content patterns and even textbooks from Serbia and Croatia, respectively, which were tainted with exclusive nationalism and denied the historical as well as current legitimacy of $\mathrm{BaH}$ as a distinct political unit, the Bosniak cantons developed a narrative of Bosnian unity since the Middle Ages which displayed a positive image of Islam and Ottoman legacy but also 
embraced Serbs and Croats and paid respect to their respective religious beliefs such as Christian orthodoxy and Catholicism.

The IC has been commissioned to control the implementation of the peace regulations. Its most powerful organ is the "High Representative" (= HR) who acts on behalf of the IC and has the right to interfere in all matters-including withdrawal or imposition of legislation as well as dismissal of staff-that are not in compliance with the Dayton Accords. In the years following the war, the IC concentrated their support for the reconstruction of the education system on rehabilitation of destroyed schools and administration buildings. Only at the end of the 1990s, the IC became aware that the Bosnian educational authorities had constructed curricula and textbooks, which fostered ethnic hatred and feelings of cultural superiority and partly neglected the status of $\mathrm{BaH}$ as an independent state. As a countermeasure, the IC initiated a process of curriculum and textbook reform. In the following, I can only shortly refer to the complex political ramifications of this process, which has already been described in detail (Torsti 2011; Karge and Batarilo 2009; Pingel 2009). Instead, I concentrate on group relations within the commissions and working groups which tried to find a consensus on how to construct educational material acceptable to the constituent peoples of $\mathrm{BaH}$ in spite of their different cultural, religious and political concepts.

The Bosnian case has a special position within the plethora of contextual constraints that shape textbook consultations of various kinds as developed by Bentrovato (this volume). One may even doubt whether it can be subsumed under the notion of "conciliatory" textbook work. Particularly in its initial state, it can rather be compared with forced international interventions such as the occupying powers executed in Germany when they withdrew Nazi textbooks and curricula and exerted strong control over the developments of new ones after the end of the Second World War.

Although the two entity ministers and the Croat deputy education minister of the Federation signed a joint agreement on textbook revision, the process would have never got into motion if the IC would not have insisted on its implementation. Furthermore, the first step was interventionist, purely negative and without an alternative for the Bosnian stakeholders. UNESCO officials partly protected by soldiers visited schools, checked textbooks and screened passages which were regarded "inappropriate" to fostering the living together of the three constituent peoples. Thus, the revision process was shaped by top-down power relations 
at its very beginning. Nevertheless, IC and ministries followed a double strategy. The process itself was conducted by local experts with the only small representation of the IC. IC, local authorities and stakeholders in education worked together in commissions and project groups, but when agreement could not be reached or results not be implemented, the IC has always the power-and the HR has used it - to impose needed measures. Therefore, it was not easy to install a feeling of consensual processing at working levels in such an unequal power structure although this is essential if education reform should be accepted by local stakeholders, in particular teachers, pupils and parents. To comply with the IC's proposals could always be interpreted as compromising with the stronger partner.

Textbook commissions were set up for the subjects of language and literature, history, geography, the environment and society as well as religion. When the consultation process started, participants mostly followed a political agenda and saw themselves as representatives of the local ministries which had nominated them. Against the intentions at least of the IC, the starting phase can be characterized as mostly antagonistic in a double meaning. The majority of the Bosnian members showed sceptical or even dismissive attitudes towards the IC. The IC propagated a multicultural approach which was - and often still is-not well understood by most of the Bosnian members-scholars from pedagogical universities and senior teachers mostly-who were not familiar with this concept and regarded it a threat to their cultural identities. They were not well informed by their ministries about procedures and aims of the commissions and entered them mostly with the feeling that the IC is about to threaten their independence in shaping their own curricula and teaching material. However, the division between IC and Bosnians did not contribute to strengthen inner-Bosnian cohesion, because the Bosnians were united in their negative attitudes towards the IC only in order to maintain their ethnically separated education systems. Thus, the commission was characterized by an international-local (or Bosnian) antagonism as well as the inner-Bosnian division between the representatives of the three constituent peoples. In the first phase, the main dividing line ran between locals and internationals because the Bosnians were united in their efforts to torpedo the IC's intentions. Yet, they had at least to agree to those revision measures which were conditioned by the observation of the Dayton Accords and therefore could not be rejected. Consequently, only a minimal understanding could be achieved meaning to take out obvious negative, discriminating and 
disparaging representations without being able to replace rejected statements through positive formulations. Under these conditions, creative and productive cooperation could not be developed and group relations did not change considerably. This meagre result complies with Hoffman's critique of Rothman's method that it would not foster but rather "stifle creativity" because common, but minimal goals are defined at an early stage after the articulation of dissent and opposing views so that no procedure of recognition is being installed (Hoffman 2004).

It took about 2-3 years of work to de-politicize to a certain extent the commissions and arouse a kind of common expert understanding. The continuation of commission work over several years without great changes in the membership contributed to creating an in-group feeling as textbook and curricula experts in school disciplines. This made members more independent from the ministries and reduced attitudes to defend their assumed ethnic particularity. One could say that the second phase according to Rothman's model had been reached. Participants started to recognize characteristics of themselves in the "others" without feeling obliged to identify with them. The distinction between in- and out-group became less important and did no longer shape the dialogue. The longer the process lasted, the less the role of the IC was contested, since the institutional framework had been set, the goals of revision in principle accepted, organizational support and expertise provided by the OSCE (Organization for Security and Co-Operation in Europe) and experts from outside even welcomed. In the longer run, the expert status took the role of a superordinate category that embraced almost all commission members and lowered the impact of political-ethnic sub-categories. Mytko (2013) refers to the same effect and quotes Warden (2011) who made the same observation in a project conducted in Moldova, a country which is linguistically and culturally divided in a similar way as $\mathrm{BaH}$. Warden corroborates that many of the history professionals were driven "by a desire to promote pedagogical change, affirm their identity as professionals, and belong to a professional community" (Warden 2011:242). Warden "found that professional identity was important" (Mytko 2013:29).

In addition and in parallel to the commissions, the IC organized training seminars for teachers, curriculum experts and textbook authors to make them familiar with new concepts and help implement the commissions' results. At the beginning, seminar members were handpicked by the ministries; later on, they were accepted on the basis of applications showing 
their expertise in the field. This selection process broadened the recruiting basis and again underscored the significance of expert knowledge.

Only at a third stage positive results could be achieved. IC and local authorities agreed on a new format of the commissions' procedures and goals. Instead of criticizing and screening already published books and approved curricula, commissions were instructed to develop general guidelines for the writing of-future-textbooks and curricula that should acknowledge the country's multi-ethnic composition without stimulating feelings of superiority or inferiority. This task stimulated a sense of cooperation, forward-looking invention and ownership. The debate was creative and dedicated to the cause at stake. A personalization of contact and individuation of members of the "other group" could be particularly observed in the disciplinary subgroups. One could say that in the end a process of decategorization of their relationship took place (Brewer and Miller 1988).

The guidelines published in the official gazette of $\mathrm{BaH}$ in January 2007 had a notable impact on textbook authors who have become more sensitive to contentious issues such as the representation of the constituent peoples or the break-up of Yugoslavia. Particularly, authors have included more tasks, questions, sources and illustrations than in older books in order to develop pupils' critical thinking and interpretative abilities (Karge 2008).

The cooperative approach was intensified through a special commission given the task to develop a "common core curriculum", i.e. to define all contents and methodologies the existing curricula of the cantons and entities have in common. This aim reminded members of this commission on commonalities of Yugoslav times which were positively connoted. This triggered a controversial discussion amongst the Bosnian members: Should the commission only define commonalties of the existing curricula or also determine what should be in common in future and so go beyond the curricula currently in force? Although some participants fervently argued that the commission should be creative and innovative and would have a mandate to put forward future curriculum changes to the ministries in order to enlarge commonalties, the majority rejected this proposal. Nevertheless, the common core curriculum that was approved in 2003 documented common features of BaH's diverse curricula landscape for the first time after the war. It enhanced the working capacities and self-respect on the Bosnian side and eased the new constructive approach to textbook revision leading to the Guidelines. 
The more a working group or commission brought political objectives and opinions to the fore in consultations, the more members were driven in their statements by social identity patterns in contrast to their personal, individual identity (Sedikides and Brewer 2001). Language plays a key role in defining one's social, ethnic or religious identity in $\mathrm{BaH}$. When the political unity broke apart in the war, also the common South Slavic language was no longer accepted as one language with different variants according to ethnicity. Instead, the Slovenian, Croat, Serb and Bosniak variants are now defined as separate languages. Consequently, the common core sub-commission on the three languages of $\mathrm{BaH}$ had severe problems to accept that all the three languages are taken into account in the curriculum and are represented in literature classes. Communication accommodation theory shows that speech acts transmit not only an argument but also a social message about the group to which the speaker wishes to belong (Giles and Coupland 1991). Different languages are strong signifiers of different group affiliations and are used in $\mathrm{BaH}$ to mark group distinctiveness. As linguistic experts, the sub-commission members' expertise lay exactly in keeping up this distinctiveness so that political and professional dimensions became more or less inseparable. It was a problem of social communication for the experts to admit that the Bosnian languages are mutually understandable and to acknowledge the "other's" languages as teaching content vis-à-vis their own group members. Therefore, seeing themselves as disciplinary experts did not help to bridge the social and political gaps within this sub-commission as in the other disciplinary sub-commissions. They could agree on a common core only at the very end of the consultations although more forced by time pressure than activated by their own conviction. Astonishingly, having reached a positive result in the end this had also a positive effect on group relations within the sub-commission. Members openly showed their pride in the successful finalization of their work, congratulated each other. Finally, the outcome created feelings of empathy and individualization.

According to an opinion poll, a clear majority of teachers was in favour of the common core curriculum. Also, the common core curriculum was remembered more often than other, more profound innovations such as the framework law on education or the textbook commissions (Karge and Batarilo 2009). However, after the common core curriculum had been secured by the first country-wide framework law on secondary and primary education in 2003, instead of building on this moderate, positive result, the IC soon lost interest in it, did not insist on developing 
it further as originally planned but changed its educational agenda in order to implement latest European standards which were no longer content oriented-like all the existing curricula in $\mathrm{BaH}$-but competency based. The common core curriculum became less important. The new pedagogical concept was unknown to most teachers and textbook authors. It needed intensive training which could only be offered by the IC and takes a long time to reach a critical mass of teachers (Pantić et al. 2011). From the point of modernization, the altered agenda could be justified but it failed to foster ownership, engagement and understanding of the reform on the Bosnian side.

Not only in this case, are local interests sacrificed to a superficial modernization favoured by the IC. The experience of joint actions such as in the core curriculum commission could be much more important for the acceptance of reform and cooperation between the ethnic groups than the implementation of up-to-date internationally acknowledged pedagogy. However, such considerations did not reach the minds of the IC.

Yet, not only inconsistencies of the IC's policy hindered educational reform to advance. The implementation and formal acknowledgement of the commissions' results needed local by-laws. Not all of the local ministries were willing to adopt appropriate cantonal laws so that these were, in the end, partly imposed by the HR. The cooperative consensus reached at working level could not always also be installed at governmental level. Here, the argumentation remained political so that every side defended its own concept and compromised only if power relations forced them to do so. At governmental level, reform work remained a power play and did not turn into an expert dialogue. The common goal was only used as a means to pursue the aims of one's own group.

Two different and often incomprehensible communication strategies meet in multinational and multicultural textbook and curriculum revision because the expert-oriented scientific debate is almost inevitably accompanied by a political meta-discourse. As conceived in its ideal form by the German philosopher Jürgen Habermas (1984), the scientific dialogue corresponds to the paradigm of an exchange of rational arguments in order to reach a common understanding free from any kind of external interests. Objectivity is secured through intersubjective rationality. According to the German sociologist Niklas Luhman (2005), political argumentation represents a counter-paradigm to truth-oriented scientific communication. It aims at legitimation of decision-making and action. If textbook revision goes beyond pure analytical work based 
on scientific methodology and intends to revise education material, the political dimension comes in. Therefore, both streams of communication often interact in textbook and curriculum revision projects. Revision projects apply different strategies to cope with this problem. Often, political issues are treated by the chairs before presented to the whole group. The PRIME group of Israeli and Palestinian teachers sometimes split up in their respective "national" groups in order to deal separately with political issues that stand in the way of reaching a common understanding (Pingel 2010b). In the Bosnian case, a clear-cut distinction between both streams could only seldom be reached so that the analytical work was often interrupted by statements which were meant to defend the ethnically tainted education policy of one's own group.

\section{EXTERNAL INTERVENTION VERSUS INTERNAL EMPOWERMENT}

The IC propagated multiculturalism as the lead concept for reforming education in $\mathrm{BaH}$ (A Message 2002). The multicultural concept has for most of the IC a persuasive power. Particularly, the Europeans conceive the Ottoman and also to a certain extent the Hapsburg Empire-which occupied Bosnia in 1878 and annexed in 1908-as a multicultural entity suiting the ethnic and religious mix-up of $\mathrm{BaH}$. Thus, they think that they would just take up this old multicultural tradition-also applied by Socialist Yugoslavia-when introducing their modern concept of multiculturalism. However, they underestimate the long tradition of ethnic and religious compartmentalization during Ottoman and partly also Hapsburg times which was only superficially covered by Tito's "brotherhood and unity" but never forgotten or totally abolished. On the contrary, ethnic nationalism taken over from the European powers in the course of the nineteenth century translated the cultural characteristics such as language, religion and behavioural patterns connected with them into a concept of political sovereignty which was alien to the form of living together under foreign domination that represented the Bosnian experience since the late Middle Ages up to the end of the First World War (Sundhausen 2003). "Multiculturalism" meets neither Bosnia's remote past, nor the Yugoslav experience; it has no equivalence in the local languages and could hardly be understood as an indigenous term that should provide the Bosnians with "ownership"; rather, it was easy to be denounced by local politicians as a foreign concept imposed on the region to establish an egalitarian culture and society. 
The problematic reputation the Bosnian District of Brcko has with most politicians and educationalists in $\mathrm{BaH}$ proves how difficult it is to break the barriers of ethnic-cultural separatism. Brcko forms a separate political unit under the surveillance of the HR. Brcko was not integrated into the Serb-dominated Republic because of its mixed population. Brcko schools use a blend of Croat, Bosniak and Serb curricula, and teachers work with textbooks from all political units. All the three South-Slav languages are used in the classroom. Although the local authorities, parents and pupils accept the Brcko education system, it is not regarded as a future model and viable alternative to ethnic separation outside of the district. Rather, it falls here under the dictum as being implemented by the IC in spite of the support it enjoys with the local population. Representatives of the education ministries were not even willing to take part in excursions to Brcko in order to study how the system works. They showed no interest in implemented multiculturalism in their country.

As the commissions' and ministers' meetings alternatively took place in Sarajewo, the Croat part of Mostar and Banja Luka, the capital of the Serb Republic, representatives of the IC proposed several times to jointly visit cultural highlights of these places in order to acknowledge cultural achievements of the three constituent peoples. This was also rejected. Also out of school activities with pupils from different ethnicities occurred only rarely. Some international organizations conducted seminars of this kind, but for most of the participants, these were unique and short-time encounters that hardly have a sustainable effect. When pupils come back to their normal, ethnically shaped environment, they fall back to their previous positions, even if they changed opinions about the "other" during the seminar (Pettigrew 1985).

Local and international NGOs, foundations and international organizations such as UNESCO, United Nations Development Programme, Council of Europe conducted a great number of projects dealing with the broad area of peace education in parallel to but often not coordinated with the official textbook revision activities. However, it is difficult to measure their influence on educational practice because most of them were not systematically evaluated. Many projects act on a shortterm basis and follow different agendas. For teachers, it is often not transparent which project to follow. Long-term perspectives and clear agendas are, however, conducive to the success of reform (Stedman and Rothchild 1996; Downton and Wehr 1997). 
Although this chapter mainly deals with history education, it is worthwhile to also look at civic education in order to better evaluate strategies of the IC vis-à-vis local interests. The citizenship education projects run by the international organization Civitas have produced a welldocumented impact on curriculum change and teaching methods. This organization tries to reach local educational authorities' agreement for conducting projects. It has been able to integrate teaching material and curricular guidelines into official curricula (Batarilo 2008) and could disseminate its approach to a considerably wider range of pupils than many other organizations. The programs include social community work, the improvement in school facilities and training of students on how to efficiently participate in school councils. Civitas reaches a great number of students in all political units of the country-the report of 2015 mentions 35,000 addressees every year for the program "Project Citizen" (News from the Center for Civic Education 2015). From time to time, projects are evaluated (Summary of Research 2000). Nevertheless, the Executive Director of Civitas $\mathrm{BaH}$ reported about problems to establish positive working relations with the educational authorities contending in an evaluation seminar that official "institutions are often unable or unwilling to engage citizen participation in local processes, and citizens, in turn, are hesitant to trust and engage in those very institutions" (Frouzesh 2005; see also Soule, n.y.). Moreover, Civitas is one of the few organizations which work on the same program and follow a coherent agenda over a long-time span. Providing continuity, coherence, involvement of authorities and students' participation in practical school and communal activities, Civitas has probably found the most effective way to train students and teachers and brought about a curricular change towards democracy and civic education replacing the Yugoslav pre-military education. Civitas had to approach all the cantonal and entity ministers. One can say that Civitas was successful in establishing a common core for the diverse civic curricula in $\mathrm{BaH}$.

Most of the NGOs and international organizations are not able to apply such a concerted bundle of coordinated processing capacity, content-oriented curricular elaboration and social engagement of students and teachers. The Greek NGO Center for Democracy and Reconciliation in South-Eastern Europe, for example, still has problems to disseminate its Joint History Project teaching material in $\mathrm{BaH}$ because of unwilling local authorities and teachers sceptical to innovations coming from outside of the country and not yet approved by the education ministries. 
In contrast to Civitas which established working relations to local educational authorities from the very beginning of their project, the Center first elaborated the material in cooperation with a group of scholars and teachers and then tried to get the authorities' support for teaching it. Its teaching material is mostly used by those-now more than 1000-teachers from Balkan countries, Turkey and Cyprus who have participated in special training seminars (Fajfer 2013). Even if most of them show positive reactions, ripple effects are often still missing.

Surveys and evaluation studies show that the majority of teachers do not simply reject innovative steps towards peace education and intercultural understanding, but they feel dependent on support from their authorities, parent organizations and school boards (Magill 2010). According to a survey conducted in the year 2008, teachers are satisfied with the formal modernization of textbooks (Karge and Batarilo 2009). They enjoy clear multi-coloured design with images, photographs and shorter texts. However, they have problems to teach content areas that do not fit into the up to now official line of emphasis on ethnic difference. Teachers feel uneasy to refer to commonalties of the three constituent peoples in history or to teach new issues such as the recent war of 1992-1995 and the break-up of Yugoslavia. Nevertheless, the majority spoke out for dealing with these topics in textbooks. Teachers and secondary school students (addressed in a smaller pilot study of the same project conducted by Karge and Batarilo 2009) wished to get more information about the consequences of the war for the current situation in $\mathrm{BaH}$. This is quite a rational result, in contrast to the often heated emotional public debates. The questionnaires were answered, and the interviews conducted during an in-service seminar on textbook reform. It may well be that teachers showed more openness to innovation in an environment where they feel being free from the context of normal school life.

\section{Flexible International Strategies of Change Versus the Perseverance of Disciplinary Local Knowledge}

As we have seen, cooperative attitudes in textbooks revision are mainly based on the acknowledgement of participants' expertise (mostly in the case of official, politically induced commissions) and/or on recognition of personality and sincerity. With which qualifications do members of the IC contribute to this process? Their professional background influences 
their reputation in commissions and negotiation strategies. Only the heads of the educational departments of UNESCO and OSCE-the IC lead organizations for education in the time period dealt with herewere professional educationalists or textbook specialists, respectively, for a relatively short period. Most of the staff involved in the commissions had received higher education although with quite different subject backgrounds. They were often specialized in social work or international relations. Many of them have worked for international organizations for a number of years but normally under short-time contracts, on different places with different organizations in various fields of intervention. Their greatest professional advantage is the acquisition of a flexible knowledge about intervention strategies in underdeveloped and conflict-ridden regions. They have acquired this knowledge mostly on the job. It builds on experience with little theoretical reflection. Their knowledge is not country specific and needs to be moulded according to the specific local needs. For example, before the OSCE took over the mandate for education, it had worked in the field of human rights issues, security policy and had helped to prepare and oversee elections. OSCE took over education without considerably enlarging its staff which was mostly transferred from the election section to the newly founded education department. To what an extent staff members get familiar with local characteristics of the issues at stake depends very much on their own initiative. Most of them have not received systematic training. The objectives of intervention are set by the agenda of the organization which they are part of. As a number of international organizations are represented in the IC, their strategies, objectives and financial means must be coordinated to speak with one voice to their local counterparts. Yet, the obligation to follow the organizations' specific agendas often counts more than the responsibility for working on a common goal.

The IC staff, therefore, brings in different strategies of intervention which already have been used in different regions and proved as generally applicable but not yet tested at the concrete site of operation. The internationally acquired knowledge meets with local, long-time professional practice in the commissions. Both could complement each other. However, given the power imbalance this unequal encounter tends to create mistrust and scepticism against the "other's" wisdom. The internationals suspect the locals to stick to their outdated and no longer applicable past experience, whereas the locals fear to be overwhelmed by content and methodology that does not fit into their context which the 
internationals do not know sufficiently. The power imbalance is supplemented by an asymmetry of knowledge which the locals often translate into an inferiority-superiority relationship. This supports mistrust and scepticism rather than developing mutual trust and cooperative attitudes. Yet, there are ways to mitigate these ruptures. The majority of the OSCE staff is made up by locals. Whereas the internationals hold mainly leading positions, most of the locals work in the many OSCE field offices (these were 14 during the height of the reform in the first decade of the twenty-first century) and are in almost daily contact with local practitioners and stakeholders. Over the years, they have acquired specific local knowledge and established positive working relations. Their reporting back to the main office and their possible intervention in the commissions' deliberations can serve as a buffer and transmitter between the local-international imbalances.

\section{On the Way to a "Narrative Transformation"?}

After approximately a decade of intense reform activities in primary and secondary education, the IC reshuffled its capacities. Different factors were to be taken into account. Firstly, the focus of international aid moved from the Balkans in general and $\mathrm{BaH}$ in particular to other regions of still open or new conflicts such as the Middle East, Africa and, later on, to Eastern Europe. The Balkans was, by and large, pacified. The OSCE education department has been downsized and now concentrates its efforts on capacity building. It no longer directly interferes in curriculum or textbooks matters. The reform agenda of the first decade of the twenty-first century has helped to install the necessary legislation in all sectors of education. It removed offensive material from schools, curricula and teaching devices. It has laid foundations for the development of multi-perspectival teaching material and modernized curricular structures. Despite these notable achievements, it did not fundamentally change the divided education system according to ethnicity, culture, language and religion. Most of the cooperative structures developed by the IC through commissions, working groups, ministers meetings did not survive the reform phase. Nevertheless, the many projects conducted by the IC and international as well as local NGOs have introduced open learning methods to a wide range of teachers and curriculum experts, strengthened parents' and pupils' participation in democratic school management and created innovative teaching material. However, 
although such activities continue, they still reach only a minority and have not yet changed the official mainstream narratives and textbook representations. The hiatus continues to exist between the ongoing official policy of separation and emphasis on ethnic difference on the one hand and engaged NGOs and innovative experts on the other hand. As long as the electorate in the Serb Republic and the Croat majority cantons favours parties that stand for ethnic separatism, a real breakthrough towards the recognition of a mixed society without intellectual, cultural and religious borderlines is hardly to be expected. One may concede that the reform work has created a "transformative potential" as it is called by Bentrovato (this volume), but this potential has only partly been activated up to now. One may doubt whether the innovative local forces have become strong enough to fully awake this potential in future or whether the traditional political institutions will exert their power to denounce it and to keep it small.

\section{Notes}

1. The International Community comprises the representatives of member states of the Peace Implementation Council and international organizations actively rebuilding $\mathrm{BaH}$.

2. "Bosnian" refers to the whole of $\mathrm{BaH}$ or all its citizens; "Bosniak" is the self-designation of BaH's Muslim population who so create their own ethnic identity vis-à-vis the "Croats" and "Serbs".

\section{REFERENCES}

Adwan, S., Bar-On, D., \& Naveh, E., Peace Research Institute in the Middle East (Eds.). (2012). Side by side. Parallel histories of Israel-Palestine. New York: The New Press.

A Message to the People of Bosnia and Herzegovina. Education Reform. (2002, November 21). (in English, Bosniak, Croat and Serb language).

Amir, Y. (1976). The role of intergroup contact in the change of prejudice and ethnic relations. In P. A. Katz (Ed.), Towards the elimination of racism (pp. 245-308). New York: Pergamon.

Bar-On, D. (1995). Encounters between descendants of Nazi Perpetrators and Descendants of Holocaust Survivors. Psychiatry,58(3), 225-245. 
Bar-On, D., \& Kassem, F. (2004). Storytelling as a way to work-through intractable conflicts: The German-Jewish experience and its relevance to the Palestinian-Israeli context. Journal of social Issues,60(2), 289-306.

Bar-On, D., Kutz, S., \& Wegner, D. (Eds.). (2000). Bridging the gap. Hamburg: Körber Foundation.

Batarilo, A. (2008). Civic education in Bosnia and Herzegovina. The inclusion of civic education into official curricula. Sarajewo, unpublished report.

Brewer, M. B., \& Miller, N. (1988). Contact and cooperation: When do they work? In P. Katz \& D. Taylor (Eds.), Eliminating racism: Profiles in controversy (pp. 315-326). New York: Plenum.

Brown, R., \& Hewstone, M. (2005). An integrative theory of intergroup contact. Advances in Experimental Social Psychology,37, 255-343.

Bush, K. D., \& Saltarelli, D. (2000). The two faces of education in ethnic conflict. Towards a peacebuilding education for children. Florence: United Nations Children's Fund, Innocenti Research Centre. Retrieved August 22, 2016, from https://www.unicef-irc.org/publications/pdf/insight4.pdf.

Downton, J., Jr., \& Wehr, P. (1997). The persistent activist: How peace commitment develops and survives. Boulder, CO: Westview.

Duveen, G. (2002). Construction, belief, doubt. Psychologie \& Société,5, 139155.

Fajfer, L. (2013). Reconnecting history-The joint history project in the Balkans. In K. V. Korostelina, \& S. Lässig (Eds.), History education and postconflict reconciliation. Reconsidering joint textbook projects (pp. 140-154). London: Routledge.

Faure, R. (2015). Netzwerke der Kulturdiplomatie. Die internationale Schulbuchrevision in Europa, 1945-1989 [Networks of cultural diplomacy. International textbook revision in Europe, 1945-1989]. Berlin: Walter de Gruyter.

Faure, E., Herrera, F., Kaddoura, A.-R., Lopes, H., Petrovsky, A. V., Rahnema, M., et al. (1973). Learning to be. The world of education today and tomorrow. Paris and Toronto: UNESCO and Ontario Institute for Studies in Education.

Fisher, W. R. (1984). Narration as human communication paradigm: The case of public moral argument. Communication Monographs,51, 1-22.

Frouzesh, S. (2005, April). Civic education in divided societies: Using civic education materials to build a democratic political culture. Summary of focus group. Retrieved April 20, 2016 form www.civiced.org/pdfs/research/ FocusGroupSummary.pdf.

Giles, H., Coupland, J., \& Coupland, N. (1991). Accommodation theory: Communication, context, and consequence. In H. Giles, J. \& Coupland, N. Coupland (Eds.), Contexts of accommodation (pp. 1-68). New York: Cambridge University Press. 
Habermas, J. (1984). Theory of communicative action (Thomas McCarthy Trans.). Boston: Beacon Press.

Hoffman, M. (2004). Peace and conflict impact assessment methodology. Berghof handbook for conflict transformation. Retrieved August 22, 2016, from http://www.berghof-handbook.net.

Karge, H. (2008). 20th century history in textbooks of Bosnia and Herzegovina: An analysis of books used for the final grades of primary school. Sarajewo: OSCE Mission to Bosnia and Herzegovina.

Karge, H., \& Batarilo, K. (2009). Norms and practices of history textbook policy and production in Bosnia and Herzegovina. In A. Dimou (Ed.), "Transition" and the politics of history education in Southeastern Europe (pp. 307-335). Göttingen: Vandenhoeck \& Ruprecht.

Kelman, H. C. (2009). A social-psychological approach to conflict analysis and resolution. In D. Sandole, S. Byrne, I. Sandole-Staroste, \& J. Senehi (Eds.), Handbook of conflict analysis and resolution (pp. 170-183). New York: Routledge.

Luhmann, N. (2005). Risk: A sociological theory (Communication and Social Order). Chicago: Aldine Transactions.

Magill, C. (2010). Education and fragility in Bosnia and Herzegovina. Paris: International Institute for Educational Planning in cooperation with UNESCO, INEE, University of Ulster. Retrieved April 20, 2016, from http://unesdoc.unesco.org/images/0019/001910/191060e.pdf.

Mytko, G. (2013). Peacebuilding in the Balkans through bistory education reform. (Master's thesis). University of Leiden. Retrieved August 22, 2016, from https://openaccess.leidenuniv.nl/bitstream/handle/1887/24162/ Thesis\%20Final\%20Draft\%20Mytko.pdf?sequence=l.

News from the Center for Civic Education. Students showcase projects in Bosnia and Herzegovina (2015, May 26). Retrieved August 20, 2016, from http:// www.civiced.org/e-news/?p=1581.

Oskamp, S. (Ed.). (2000). Reducing prejudice and discrimination. The Claremont symposium on applied social psychology. Mahwah, NJ: Erlbaum.

Pantić, N., Wubbels, T., \& Mainhard, T. (2011). Teacher competence as a basis for teacher education: Comparing views of teachers and teacher educators in five Western Balkan countries. Comparative Education Review,55(2), 165-188.

Perikleous, L., \& Shemilt, D. (Eds.). (2011). The future of the past. Why history education matters. Nicosia: The Association for Historical Dialogue and Research.

Pettigrew, T. F. (1985). The contact hypothesis revisited. In M. Hewstone \& R. Brow (Eds.), Contact and conflict in intergroup encounters (pp. 169-195). Oxford: Blackwell. 
Pettigrew, T. F. (1998). Intergroup contact theory. Annual Review of Psychology, 49, 65-85.

Pingel, F. (2009). From ownership to intervention-Or vice versa? Textbook revision in Bosnia and Herzegovina. In A. Dimou (Ed.), "Transition" and the politics of history education in Southeastern Europe (pp. 251-305). Göttingen: Vandenhoeck \& Ruprecht.

Pingel, F. (2010a). UNESCO guidebook on international textbook research and textbook revision. 2nd, rev. and extended ed., Braunschweig and Paris: Georg Eckert Institute and UNESCO.

Pingel, F. (2010b). Geschichtsdeutung als Macht? Schulbuchforschung zwischen wissenschaftlicher Erkenntnis- und politischer Entscheidungslogik [The power of interpreting history. Textbook research between science and politics]. Journal of Educational Media, Memory, and Society,2, 93-112.

Pingel, F. (2016). Textbook revision programme: History, concepts, and assumptions. In A. Kulnazarova, \& C. Ydesen, (Eds.), UNESCO without borders. Educational campaigns for international understanding (pp. 13-31). New York: Routledge.

Rothman, J. (1997). Resolving identity-based conflict in nations, organizations and communities. San Francisco, CA: Jossey-Bass.

Rouhana, N. N., \& Kelman, H. C. (1994). Promoting joint thinking in international conflicts: An Israeli-Palestinian continuing workshop. Journal of Social Issues, 50, 157-178.

Sedikides, C., \& Brewer, M. C. (Eds.). (2001). Individual self, relational self, collective self: Partners, opponents, or strangers?. Philadelphia: Psychology Press.

Seitz, K. (2004). Education and conflict. The role of education in the creation, prevention and resolution of societal crises. Consequences for development cooperation. Stuttgart: Deutsche Gesellschaft für Technische Zusammenarbeit (GTZ).

Shultziner, D. (2010). Struggling for Recognition. The psychological impetus for democratic progress. New York: The Continuum International Publishing Group.

Smith, A., \& Vaux, T. (2002). Education, conflict and international development. Report commissioned by the UK Department for International Development.

Soule, S. (n.d.). Beyond communism and war. The effect of civic education on the democratic attitudes and behavior of Bosnian and Herzegovinian Youth. Calabasas, CA: Center for Civic Education.

Stedman, S., \& Rothchild, D. (1996). Peace operations: From short-term to long-term commitment. International Peacekeeping,3(2), 17-35.

Summary of Research: Project Citizen in Bosnia and Herzegovina (2000). Project citizen in Bosnia and Herzegovina. Retrieved August 20, 2016 from http://www.civiced.org/papers/research_bih_summary.html.

Sundhausen, H. (2003). Staatsbildung und ethnisch-nationale Gegensätze in Südosteuropa [State building and ethnic-national antagonism in Southeastern Europe]. Aus Politik und Zeitgeschichte, B 10-11, 3-9. 
Tajfel, H., \& Turner, J. C. (1986). The social identity theory of intergroup behavior. In S. Worchel \& W. G. Austin (Eds.), Psychology of intergroup relations (pp. 7-24). Chicago: Nelson-Hall.

Tawil, S., \& Harley, A. (Eds.). (2004). Education, conflict and social cohesion. Geneva: UNESCO International Bureau of Education.

Torsti, P. (2011). How to deal with a difficult past? history textbooks supporting enemy images in post-war Bosnia and Herzegovina. In T. Abba (Ed.), Education in Eastern Europe, Central Eurasia, South Asia and South East Asia (pp. 65-86). London: Routledge.

Turner, J. C., Hogg, M. A., Oakes, P. J., Reicher, S. D., \& Wetherell, M. S. (1987). Rediscovering the social group: A self-categorization theory. New York: Basil Blackwell.

UNESCO (2000). The Dakar framework for action. education for all: Meeting our collective commitments. Adopted by the World Education Forum, Dakar, Senegal, 26-28 April 2000. Paris: UNESCO. Retrieved August 22, 2016 from http://unesdoc.unesco.org/images/0012/001211/121147e.pdf.

Warden, E. (2011). The "Mock Reform" of history education in Moldova: Actors versus the script. Comparative Education Review, 55(2), 231-251.

\section{Author Biography}

Falk Pingel Ph.D., is an Associated Research Fellow at the Georg Eckert Institute for International Textbook Research in Braunschweig/Germany. $\mathrm{He}$ was for many years the Institute's Deputy Director. Since his retirement in 2009, he is a consultant on issues of textbook and curriculum research and revision to governmental and academic institutions as well as international organizations. $\mathrm{He}$ has been particularly involved in projects dealing with the representation of conflicting identities, for example in South Africa, the Middle East and East Asia. In 2003/2004, he was the first Director of the OSCE's Education Department in Sarajewo/Bosnia and Herzegovina. Falk Pingel also taught contemporary history as well as theory and didactics of history at Bielefeld University. Amongst his publications is the UNESCO Guidebook on International Textbook Research and Textbook Revision (Braunschweig/Paris, 2010 $)$. He co-edited (in conjunction with U. Han, T. Kondo and B. Yang) History Education and Reconciliation. Comparative Perspectives on East Asia, (Frankfurt/M, 2012). 
Open Access This chapter is licensed under the terms of the Creative Commons Attribution 4.0 International License (http://creativecommons.org/licenses/ by $/ 4.0 /)$, which permits use, sharing, adaptation, distribution and reproduction in any medium or format, as long as you give appropriate credit to the original author(s) and the source, provide a link to the Creative Commons license and indicate if changes were made.

The images or other third party material in this chapter are included in the chapter's Creative Commons license, unless indicated otherwise in a credit line to the material. If material is not included in the chapter's Creative Commons license and your intended use is not permitted by statutory regulation or exceeds the permitted use, you will need to obtain permission directly from the copyright holder.

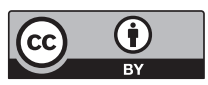

